\title{
Chatbot as Rural Extensionist for Small Beekeepers
}

\author{
Aloísio Alkmim de Oliveira Filho \\ Computer Science Department- Universidade de Salvador (UNIFACS) \\ Salvador, Ba - Brasil - aloisioalkmim@outlook.com
}

\begin{abstract}
Beekeeping is an important activity for the country, generating jobs and income for several rural families. However, the lack of technical assistance reduces the chances of success in production. So our objective with this work was to create a chatbot capable of taking technical assistance to small producers. We created the chatbee and delivered it to beekeepers and small producers who intend to enter the area, and at the end of 90 days we sent a form with some questions to be answered, and from the answers we realized that the function of bringing technical assistance was carried out by the chatbot.

Resumo. A criação de abelhas é uma atividade importante para o país, gerando emprego e renda para diversas familias do campo. Entretanto a falta de assistência técnica reduz as chances de sucesso na produção. Assim nosso objetivo com o presente trabalho foi criar, um chatbot capaz de levar assistência técnica para pequenos produtores. Criamos o chatbee $e$ entregamos para apicultores e pequenos produtores que pretendem entrar na área, e no final de 90 dias enviamos um formulário com algumas perguntas para serem respondidas, e pelas respostas percebemos que a função de levar assistência técnica foi comprida pelo chatbot.
\end{abstract}

\section{Introduction}

According to Schönardie (2017), rural extension is a historical reality, no matter the semantic meaning given, being the main idea, educational, performed. Rural extension has been carried out for at least more than 50 years in Brazil, fulfilling its educational function in rural areas, not limited only to the dissemination of technologies and modernization of agriculture. It also transmits social organization and domestic economy to those involved. We know that in Brazil, rural extension is scarce in several regions, such as the North and Northeast regions. Small producers are the most affected by this data. Since many cannot afford to pay a professional to assist them, they are hostages of the rural extension offered by the government, which often does not reach them (IBGE 2017).

Technological advances have allowed the creation of new intelligent and autonomous systems, as is the case of the chatbot, being a software capable of communicating with the user by means of natural language. ELIZA was the first autonomous conversational agent, emulating a psychotherapist (Weizenbaum 1966). 
The application of a chatbot today is very diverse, being found in e-commerce, educational support, customer service and other applications. And another fact that must be taken into account nowadays is the popularization of smartphones, being one of the main means of access to the internet in Brazil and consequently one of the largest sources of acquiring knowledge (IBGE 2017). Making this data more relevant is the democratization of the internet in rural areas, between 2006 and 2017 there was an increase of $1900 \%$ of internet points in rural areas (IBGE 2017). This facilitates the adoption of new technologies for rural areas.

Beekeeping in Brazil represents employment and income for many families, being an agricultural activity of extreme importance, since bees perform a great environmental role, pollination. Among the products produced by bees, we have honey as the highlight, being the main objective of beekeeping in the country. Being an activity with constant growth, in the year 2021 there was an increase of $112 \%$ compared to 2019 according to Canal Rural (2021). This leverage occurred in 2001 when the country began to export its production to the United States and Europe, since previously the production was only to meet domestic demand.

\section{Beekeeping}

The emergence and proliferation of bees on Earth is thought to have occurred closely with the emergence of the angiosperms millions of years ago. The ancestors of bees were insects that collected nectar as an energy source and hunted small animals that complemented their protein source. When these insects replaced animal protein with vegetable protein and started consuming pollen from flowers, they began a life story of their own. On the other hand, the angiosperms evolved in their floral morphology, adapting their floral structures, thus ensuring the success of pollination by these insects. This explains the great diversity of colors, shapes and smells observed in today's flowers (Vieira et al, 2004).

Beekeeping is a branch of animal husbandry specialized in the production of bees, for the production of honey, wax, pollen, propolis, royal jelly, and "bee bread". Thus the rural producer can derive several products from a single activity. The Africanized Apis melifera is the most used species in the country, however this species was bred in the country with the.

The importation of African bees by the Brazilian government in 1956, to obtain greater productivity. This activity began in Brazil in the years 1839, with the priest Antonio Carneiro, and today is a highlight in agriculture and livestock in the issue of sustainability and environmental preservation. Currently the largest exporters of honey are Argentina representing about $84.17 \%$ and China representing about $26.59 \%$ of world exports (USDA 2019). Being an activity of low investment and fast economic return, it can even share the space with other activities of animal production, such as cattle farming, and widely used in plant production. 


\section{Rural Extension}

Historically, this term began in the 19th century, with the extensions practiced by English universities. In the 20th century, in the United States, the cooperative rural extension service was created, bringing together several universities and consolidating the term rural extension (Jones and Garforth, 1997). This term means to take or transmit knowledge from its generating source to the rural public, having a broader sense as the educational process of communication (Peixoto, 2008). This work of taking knowledge to small producers has a very significant role, since it offers the rural public a perspective of future for them and their families, and thus, consequently, decreasing the rural exodus, in search of improvements in the quality of life.

Because it is a country of continental sizes, offering rural extension to all producers becomes something of a challenge. With this, we can observe some data such as the HDI, human development index. Regions with high indicators have greater access to rural extension, as is the case of the Southern region of the country, with $48.6 \%$ of the total assistance offered and with an HDI of 0.831 . The Northeast region of the country had only $7.4 \%$ and an HDI of 0.608 (IBGE 2017).

Just as many producers in these regions have financial difficulties, often caused by poor production in their herd. Paying a private technician becomes an unfeasible activity. This makes it difficult for these families to stay in the rural environment.

\section{Chatbot}

The term chatbot comes from the junction of two English words, Chat (Conversation) and bot (Robot). Thus the chatbot is a system that is to perform the human-computer interaction through natural language, for Carrera \& Krüger (2020) the presence of artificial intelligence software such as chatbots, with varying degrees of autonomy and purposes, symbolizes the breakdown of the essentiality of human presence in networks. Gomes (2017) the use of this technology represents significant changes in society. Thus the chatbot can be based on two characteristics, rules and artificial intelligence, in the model in rules is limited to a set of well-defined rules, not having the ability to learn, while those with the characteristic of artificial intelligence, have the ability to learn and are more realistic in communication with the user.
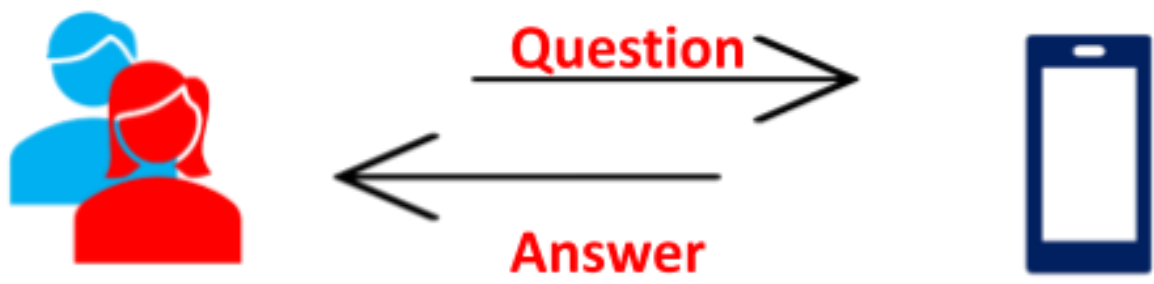

Figure 1. Chatbot Design 
As we can see from image 1, the operation of the chatbot requires the input of data that will be to the platform, through Natural Language Processing. The character sequences are converted into objects and are properly handled by the agent, considering the defined machine learning pattern and thus returning to the user.

\section{Chatbot Development}

The chatbot was developed by the Google ${ }^{\circledR}$ artificial intelligence platform, Dialogflow ${ }^{\circledR}$, with closed source code, but it is integrated with major messaging applications such as Telegram ${ }^{\circledR}$, Slack $\AA$, among others. For this project, the application chosen was Telegram ${ }^{\circledR}$, for being widely diffused by the target audience in relation to other available applications. The system consists of answering pre-defined questions referring to beekeeping production. The software allows you to add new answers to the database, and the language used in this communication is Portuguese.

Messages sent to the chatbot are redirected to the platform through Natural Language Processing. The strings of characters are converted into objects and are properly handled by the agent, considering the defined machine learning pattern and thus returning to the user. This training is done automatically by the platform. The interactions allow the agent to understand the motivation through a specific user input. Thus entities extract useful data from natural language inputs and use this information to send the interaction that best fits the user's request. In this way the context controls the flow of conversations, allowing the agent to convey this information to parameters; which are structured data that can be used to generate responses. The operation occurs as follows, the messages sent by the user will be transformed into objects by dialogflow ${ }^{\circledR}$ and the system agent understands this motivation and searches for the best external action in the database created. Returning to the dialogflow ${ }^{\circledR}$ that will send this interaction to the user. Thus, we can see that the Google ${ }^{\circledR}$ artificial intelligence system performs the intercession between the user and the performance of the activity. With Dialogflow it is possible for the user to send and receive audio messages, but for the chatbee we left only the text interaction.

\section{Using Chatbot}

The Chatbee is intended to elucidate the production of beekeeping. It has the distinguishing characteristic of being simple to understand, by sending short texts along with images and YouTube ${ }^{\circledR}$ video recommendations, when necessary, to facilitate the understanding of the small rural producer. We sent the access link to the chatbot to 20 small rural producers who intended or practiced bee production. These small farmers had no rural technical support, but knew how to use messaging applications.

It was informed to these producers that any doubt they had should go directly to the chatbot, and at the end of a 90 day period a form with some questions would be sent. This 90 day interval refers to a period of colony recovery and increased production. 
With two types of forms, one form for those who performed the activity and another form for those who intended to enter the activity

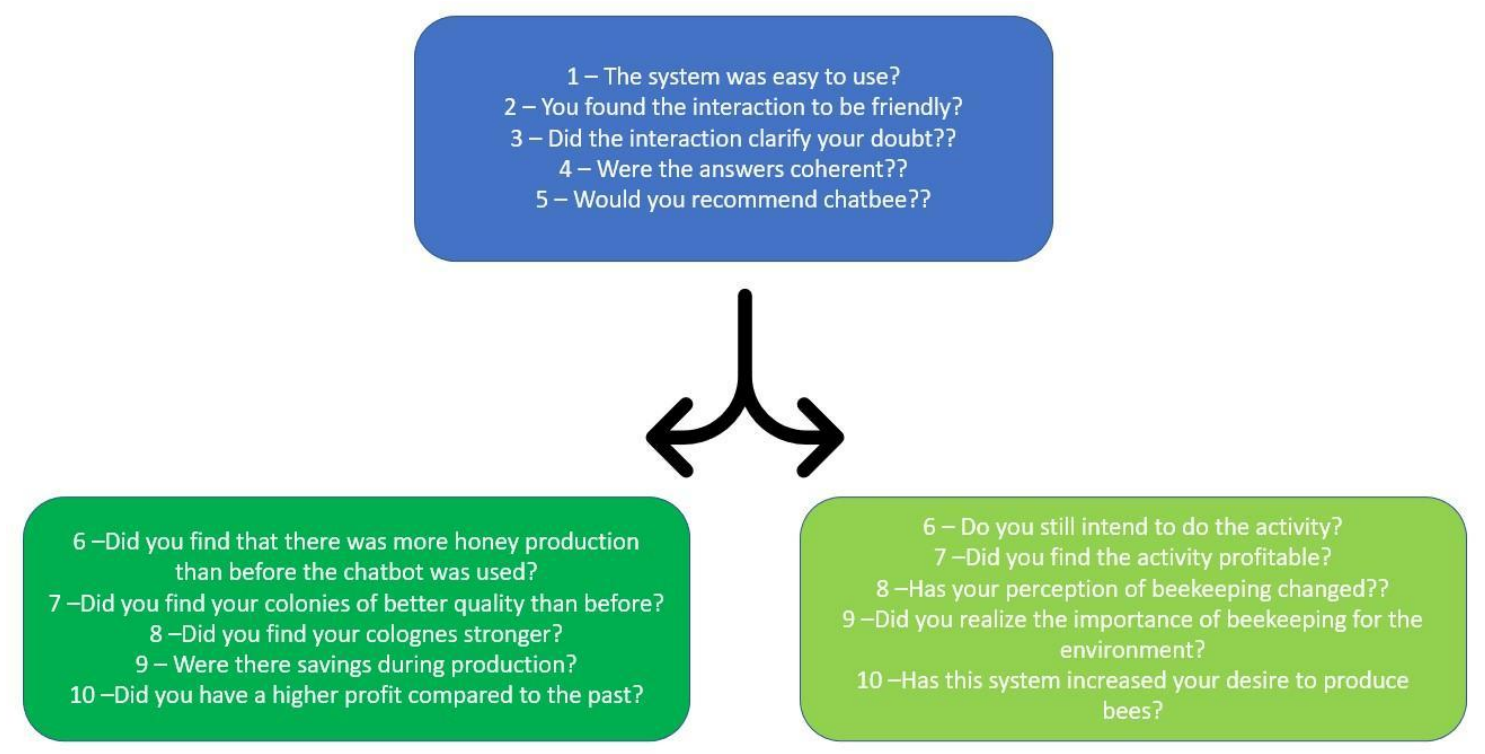

Figure 2. While the green block on the right was sent to beekeepers. The green block on the left, on the other hand, was questions sent to those who intend to carry out beekeeping production.

\section{Results and Discussion}

We had 20 producers. Ten of them had their own smartphone, and ten did not. In relation to the first questions concerning the first block, we had positive data, showing that small rural producers are increasingly familiar with this type of system, not getting big noises. The first question regarding the ease of using the system, $80 \%$ of the producers said it was easy, showing that it is an easy system to use. The second question, if the interaction was friendly, $75 \%$ said yes, this is due to its construction, since we were concerned in leaving the most "human" environment possible, so the bot asked the user if he was well and showed happiness to those who said they were well and concern to those who said otherwise. Now if the interaction clarified the doubt of the producer, we had the same percentage of the last question, showing that it has a good data base and in relation to the $25 \%$ that answered no, we will investigate what happened and what was asked by the user. If the answers were coherent $90 \%$ of the producers said yes, showing that the bot was well trained. And once again all the producers had interest in passing this technology forward, so we can see that it was something that offered technical support and quality and easy to understand for small producers.

In the second block, for farmers, we had another very positive result, 7 out of 10 farmers realized that there was an increase in the honey production of their colonies, due to the applications of the practices indicated by the chatbot. And $90 \%$ of the farmers 
realized that the colonies had gained a higher quality and were consequently stronger and this reflects in the honey production. Another noticeable point is that $80 \%$ of the producers realized that there was a saving during production, consequently there was a higher profit in their production, as they answered. The $20 \%$ who answered that there was no difference, we will investigate and so understand what happened. For those who did not produce, but intended to produce, we continue to have a positive result, $80 \%$ of the small rural producers who used the chatbee for 90 days, continued intending to perform the activity. Thus, we can see that there was a clarification of the productive phase and this same percentage realized that it is a profitable activity. Another important fact to note is that $100 \%$ of these future producers have changed their perception about beekeeping, and this change is a prospect of success for production, since chatbee treats production as a business and not as a pet. It is interesting to note that all 10 producers answered that they saw the importance of beekeeping for the environment. And $80 \%$ said that chatbee increased their desire to be beekeepers, being due to the perception of profit and technical assistance that this system offered.

\section{Conclusion}

As we can see the use of chatbot as a rural extension tool is a tool that can be used in beekeeping production. Offering quality technical assistance and thus provide more income for producers. It can offer quality of life to small beekeepers, since those who used the system reported higher productivity in production.

\section{References}

Abelha: Apicultura no Brasil. 2012 disponível em: < https://abelha.org.br/apicultura-nobrasil/> Acessado dia 20/07/2021

Canal Rural: Exportação de mel brasileiro cresce 112\% em 2021; veja os principais destinos. 2021 disponível em: $<$ https://www.canalrural.com.br/noticias/exportacaode-mel-brasileiro-cresce-112-em2021-veja-os-principais-destinos/> Acessado dia 20/07/2021

Carrera, F. \& Kruger, P. (2020). Publicidade inteligente: convergências entre os chatbots e as marcas. Signos do Consumo12(1), 27-41, São Paulo, jan/jun.

DIALOGFLOW. Dialogflow Enterprise Edition BETA. 2017. https://cloud.google.com/dialogflow-enterprise/. Accesso em: 02/07/2021

IBGE: Censo Agropecuário 2017. https://sidra.ibge.gov.br. 2017. Disponível em Acessado dia 02/07/2021

Gomes, C. (2017). Chatbot: entenda tudo sobre o assunto. Recuperado de http://blog. simply.com.br/chatbot/

GRAEFF, I. A Apicultura como instrumento de educação ambiental no contexto social, econômico e ambiental. Monografia de especialização - Centro de Ciências Rurais, Universidade Federal de Santa Maria. 2011

JACOBI, R. EDUCAÇÃO AMBIENTAL, CIDADANIA E SUSTENTABILIDADE 
Cadernos de Pesquisa, n. 118, março/ 2003 Cadernos de Pesquisa, n. 118, p. 189-205, março/ 2003

JONES, Gwyn E. and GARFORTH, Chris. "The history, development, and future ofagriculturalextension", in Swanson, Burton E., Bentz, Robert P. andSofranko, Andrew J. (eds.). Improvingagriculturalextension -A reference manual. Rome: Food andAgricultureOrganizationofthe United Nations, 1997, 316 p.

LIMA, S. A. M. A Apicultura como alternativa social, econômica e ambiental para o XI mesorregião do noroeste do Paraná. Dissertação do programa de pós-graduação em engenharia florestal do setor de ciências agrárias da universidade federal do Paraná.

Curitiba, PR, 2005.

MATOS, M. C. F. G. PANORAMA DA EDUCAÇÃO AMBIENTAL BRASILEIRA A PARTIR DO V FÓRUM BRASILEIRO DE EDUCAÇÃO AMBIENTAL Dissertação de Mestrado apresentada ao Programa de Pós-Graduação em Educação, Faculdade de Educação, Universidade Federal do Rio de Janeiro. 2009

PEIXOTO, M. EXTENSÃO RURAL NO BRASIL -UMA ABORDAGEM HISTÓRICA

DA LEGISLAÇÃO, Textos para discussão, Brasília, № 48, outubro2008

SCHÖNARDIE, P. A. A relação da educação do campo com os paradigmas agrários. Revista Reflexão e Ação, Santa Cruz do Sul, v. 25, n. 2, p. 196-214, 2017. Doi: 10.17058/rea.v25i2.5066

UNITED STATES DEPARTMENT OF AGRICULTURE - USDA. National honey report. Jan. 2019. Disponível em: <www.marketnews.usda.gov/mnp/fv-home>. Acessado em 20/07/2021

VIEIRA, G.H.C. et al. Uso da Apicultura como Fonte Alternativa de Renda para Pequenos e Médios Produtores da Região do Bolsão, MS. Anais do $2^{\circ}$ Congresso Brasileiro de Extensão Universitária Belo Horizonte - 12 a 15 de setembro de 2004

WEIZENBAUM, Joseph. ELIZA - a computer program for the study of natural language communication between man and machine. Communications of the ACM, v. 9 , n. 1, p. 36-45, 1966. 